\title{
Southern Hemisphere Climate Change: Re-coring Lynch's Crater
}

\author{
R. Wüst
}

School of Earth Sciences, James Cook University, Townsville QLD 4811, Australia; raphael.wust@jcu.edu.au

The Atherton Tablelands in tropical NE-Queensland, Australia, contains several good locations that record paleoclimate changes for the southern hemisphere. Lynch's Crater $\left(\mathrm{S} 17^{\circ} 21^{\prime}, \mathrm{E} 145^{\circ} 41^{\prime}\right)$ contains the longest peat and lake sediment record, spanning the last $\sim 200,000$ years (Kershaw, 1978; Kershaw, 1986). Previous studies were based on a 60-m-long core recovered with a hollow auger drill system. Unfortunately, storage and earlier investigations have left only a few crumbs of the original material.

In the mid 1990s, Peter Kershaw (Monash University, Melbourne) and Chris Turney (Queens University, Belfast) decided to investigate anthropogenic influence and to track volcanic activity, based on material recovered with a Livingston-corer (16 $\mathrm{m}$ deep). The work revealed the potential of the site as a record for human arrival in NE-Australia (Turney et al., 2001) and showed its sensitivity to ENSO strength (Turney et al., 2004).

I arrived at James Cook University in Townsville in 2002 and saw the opportunity to move my research focus from tropical peatlands to peatland and lake deposits from the southern hemisphere. Inspired by the earlier work of Peter Kershaw and the latest findings by Chris Turney, we decided to apply for project support to re-core and investigate a complete lake record from Lynch's Crater, so as to extend the initial record. While the applications to the Australian Research Council were pending in 2003, the National Geographic funded drilling with Damien Kelleher and his 4WD truck-mounted drill-rig from the Research School of Earth Sciences at the Australian National University (ANU). We used a hollow auger system that could recover 62-mm-thick core material with both wire-line or rod techniques. Unfortunately, bad weather and the sediment properties only enabled us to recover 20 $\mathrm{m}$ with a poorly preserved stratigraphy.
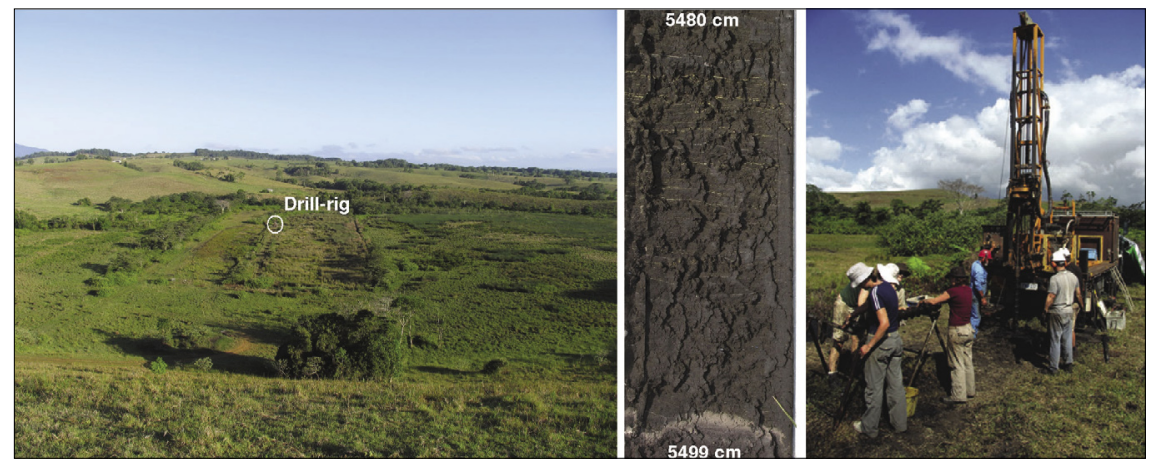

Fig. 1: Left: View from the crater rim south with location of drill site. Middle: Core section from the lower part of the core (5,480-5,499 cm depth) with finely laminated lake sediments overlying a graded bed at the bottom. Right: ANU drill-rig with hollow auger system in action on site.

Additional funding from a James Cook University Program Grant was used to return to Lynch's Crater in October 2004 but frustratingly the first hole at a different site produced similar results, despite using a modified drill (a sediment lock-out mechanism using a diaphragm at the end of the head auger and a core catcher). During a relocation of the drill rig closer to the site where the drilling was completed in the 1970s, new ideas about the sediment properties surfaced. We realized that the sediment in the subsurface was not under hydrostatic or hydrologic pressure as previously assumed when sediment shot up the augers but that the auger head was disturbing the sediment in such a way that it drew the water towards the head and liquefied the sediments. We adjusted the system so that the core barrel was at least an auger length in advance of the rotating lead auger in order to avoid liquefaction and pressure build-up around the head. Once these changes were made, we recovered a complete sequence of peat (top $15 \mathrm{~m}$ ) and laminated lake sediments (including graded beds) to a depth of $64 \mathrm{~m}$.

Multi-proxy analyses such as tephrachronology, palynology, geochemistry, mineralogy, etc., will be carried out by a diverse group of researchers and funding from the following grants: ARC Discovery (Wust, Kershaw, Anderson), ARC QEIl (Turney), National Geographic (Turney, Kershaw), JCU PG (Wust,
Heimann, Smithers, Ridd), AINSE (Muller).

The following institutions and scientists were engaged in the drilling of Lynch's Crater in 2004:

- Australian National University, Canberra: Damien Kelleher

- Monash University, Melbourne: Peter Kershaw, Susan Rule, Jono Brown

- University of Wollongong: Chris Turney

- Queens University, Belfast: Sarah Davies

- University of Queensland, Brisbane: Patrick Moss

- Florida International University, Miami: William Anderson

- Imperial College, London: Malin Kylander

- James Cook University, Townsville: Raphael Wust, Joanne Muller, Toni Williamson

\section{REFERENCES}

Kershaw, A.P., 1978: Record of last interglacial-glacial cycle from northeastern Queensland. Nature, $\mathbf{2 7 2}$ : 159-161.

Kershaw, A.P., 1986: Climatic change and Aboriginal burning in north-east Australia during the last two glacial/interglacial cycles. Nature, 322: 47-49.

Turney, C.S.M., Kershaw, A.P., Clemens, S.C., Branch, N., Moss, P.T. and Fifield, L.K., 2004: Millennial and orbital variations of El Niño/Southern Oscillation and high-latitude climate in the last glacial period. Nature, 428: 306-310.

Turney, C.S.M., Kershaw, A.P., Moss, P., Bird, M.I., Fifield, L.K., Cresswell, R.G., Santos, G.M., Di Tada, M.L., Hausladen, P.A. and Zhou, Y., 2001: Redating the onset of burning at Lynch's Crater (North Queensland): implications for human settlement in Australia. Journal of Quaternary Science, 16(8) 767-771. 